\title{
242-16H (2H) EVAPORATOR POT SAMPLING FINAL REPORT
}

\author{
D. Krementz \\ W. Y. Cheng
}

June 2008

Robotics, Remote \& Specialty Equipment Section Engineered Equipment and Systems Directorate Savannah River National Laboratory

Aiken. SC 29808 


\title{
DISCLAIMER
}

This report was prepared by Washington Savannah River Company (WSRC) for the United States Department of Energy under Contract No. DE-AC09-96SR18500 and is an account of work performed under that contract. Neither the United States Department of Energy, nor WSRC, nor any of their employees makes any warranty, expressed or implied, or assumes any legal liability or responsibility for the accuracy, completeness, or usefulness, of any information, apparatus, or product or process disclosed herein or represents that its use will not infringe privately owned rights. Reference herein to any specific commercial product, process, or service by trademark, name, manufacturer or otherwise does not necessarily constitute or imply endorsement, recommendation, or favoring of same by WSRC or by the United States Government or any agency thereof. The views and opinions of the authors expressed herein do not necessarily state or reflect those of the United States Government or any agency thereof.

\author{
Printed in the United States of America \\ Prepared For \\ U.S. Department of Energy
}


Key Words: evaporator

sample

sampling

Retention: Indefinite

\title{
242-16H (2H) EVAPORATOR POT SAMPLING FINAL REPORT (U)
}

\author{
D. Krementz \\ W. Y. Cheng
}

June 2008

Robotics, Remote \& Specialty Equipment Section Engineered Equipment and Systems Directorate Savannah River National Laboratory Aiken, SC 29808

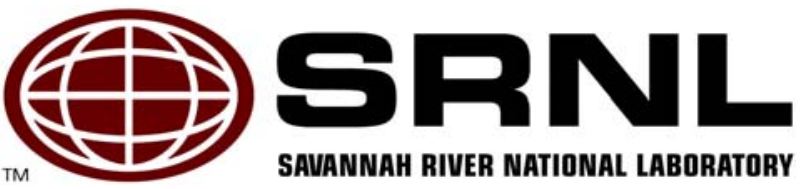




\section{REVIEWS AND APPROVALS}

\section{AUTHOR(S):}

D. Krementz, Author, Remote \& Specialty Equipment

Date

W. Y. Cheng, Author, Remote \& Specialty Equipment

Date

\section{TECHNICAL REVIEWER:}

N. J. Vrettos, Technical Review, Remote \& Specialty Equipment

Date

\section{APPROVERS}

A. Fellinger, Manager, Remote \& Specialty Equipment

Date

S. L. Marra, Manager, Robotics, Remote \& Specialty Equipment

Date

D. J. Martin, Manager, Liquid Waste Process Engineering- Criticality/Chemistry

Date 


\section{EXECUTIVE SUMMARY}

Due to the materials that are processed through $2 \mathrm{H}$ Evaporator, scale is constantly being deposited on the surfaces of the evaporator pot. In order to meet the requirements of the Nuclear Criticality Safety Analysis/Evaluation (NCSA/NCSE) for $2 \mathrm{H}$ Evaporator, inspections of the pot are performed to determine the extent of scaling. Once the volume of scale reaches a certain threshold, the pot must be chemically cleaned to remove the scale. Prior to cleaning the pot, samples of the scale are obtained to determine the concentration of uranium and plutonium and also to provide information to assist with pot cleaning.

Savannah River National Laboratory (SRNL) was requested by Liquid Waste Organization (LWO) Engineering to obtain these samples from two locations within the evaporator. Past experience has proven the difficulty of successfully obtaining solids samples from the $2 \mathrm{H}$ Evaporator pot. To mitigate this risk, a total of four samplers were designed and fabricated to ensure that two samples could be obtained. Samples had previously been obtained from the cone surface directly below the vertical access riser using a custom scraping tool. This tool was fabricated and deployed successfully. A second scraper was designed to obtain sample from the nearby vertical thermowell and a third scraper was designed to obtain sample from the vertical pot wall. The newly developed scrapers both employed a pneumatically actuated elbow. The scrapers were designed to be easily attached/removed from the elbow assembly. These tools were fabricated and deployed successfully. A fourth tool was designed to obtain sample from the opposite side of the pot under the tube bundle. This tool was fabricated and tested, but the additional modifications required to make the tool field-ready could not be complete in time to meet the aggressive deployment schedule.

Two samples were obtained near the pot entry location, one from the pot wall and the other from the evaporator feed pipe. Since a third sampler was available and all of the radiological controls were in place, the decision was made to obtain a third sample. The third sampler dropped directly below the riser to obtain a scrape sample from the evaporator cone. Samples were obtained from all of these locations in sufficient quantities to perform the required analysis. 


\section{TABLE OF CONTENTS}

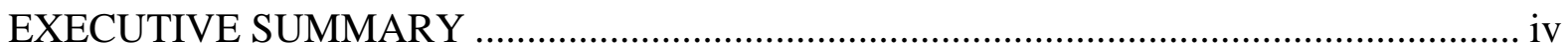

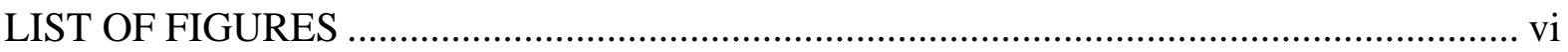

LIST OF ACRONYMS …………............................................................................ vi

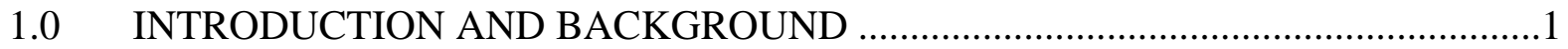

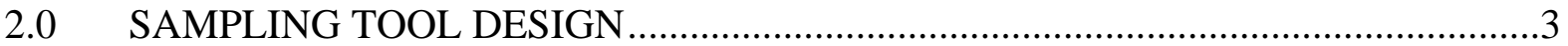

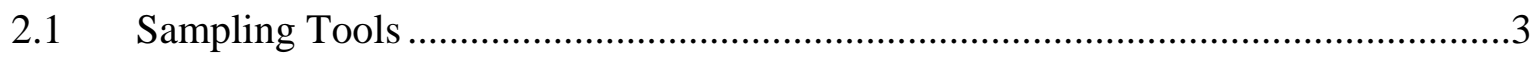

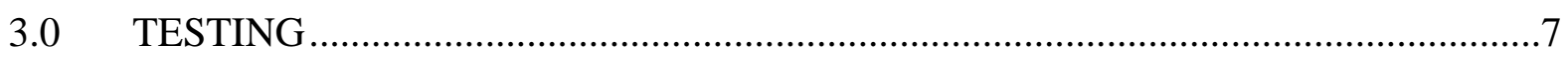

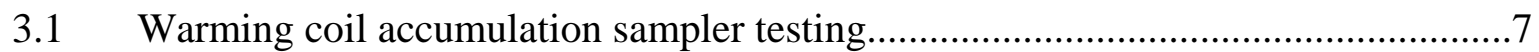

3.2 Wall scraper, thermowell scraper and cone scraper testing........................................

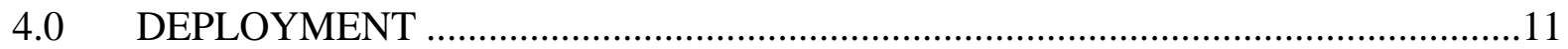

5.0 SHIPMENT AND UNLOADING OF SAMPLES FOR ANALYSIS .........................15

6.0 LESSONS LEARNED AND SUGGESTED IMPROVEMENTS ……......................17

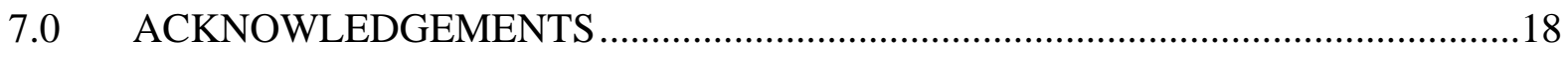

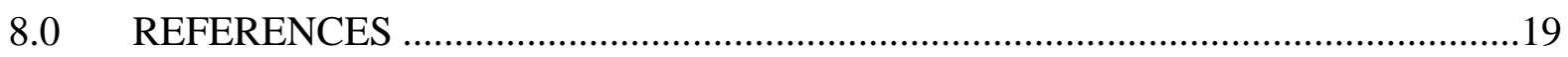




\section{LIST OF FIGURES}

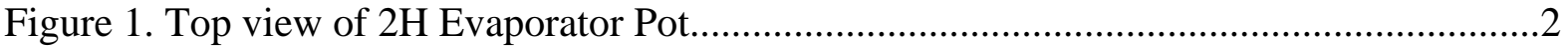

Figure 2. Cross section of 2H Evaporator through inspection riser (nozzle B) ........................2

Figure 3. Warming coil accumulation sampler with vial snapper end effector .......................4

Figure 4. Vial snapper end effector for warming coil accumulation sampler .........................4

Figure 5. Drill \& chisel end effectors for warming coil accumulation sampler .......................5

Figure 6. Elbow mechanism for wall scraper \& thermowell scraper ....................................6

Figure 7. Wall scraper \& thermowell scraper- sample cup removal method ..........................6

Figure 8. Right-left: $45^{\circ}$ thermowell, $30^{\circ}$ thermowell \& wall scrapers ..................................7

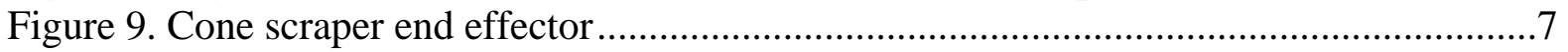

Figure 10. Wall \& thermowell mockup ..........................................................................9

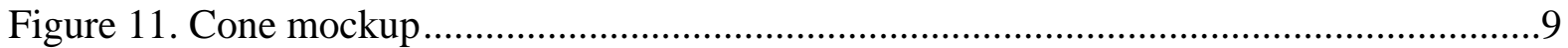

Figure 12. Scraper container with lid removed..............................................................11

Figure 13. Scraper container with lid installed ....................................................................11

Figure 14. Glove bag used during sampling ....................................................................12

Figure 15. Video goggles used during operation of sampling equipment ............................12

Figure 16. Sampler mast clamp ................................................................................13

Figure 17. Scraping the evaporator pot wall, arm camera view .......................................14

Figure 18. Scraping the thermowell, mast camera view ...................................................14

Figure 19. Scraping the thermowell, arm camera view .......................................................14

Figure 20. Scraping the cone, scraper \& camera submerged.............................................15

Figure 21. Wall sample recovered for analysis (HTF-08-28)..........................................16

Figure 22. Feed line sample recovered for analysis (HTF-08-29) .....................................16

Figure 23. Cone sample recovered for analysis (HTF-08-30) ...........................................16

Figure 24. Improved glove bag for future deployments ..............................................17

\section{LIST OF ACRONYMS}

$\begin{array}{ll}\text { 3-D } & \text { 3-dimensional } \\ \text { CA } & \text { Contamination Area } \\ \text { ID } & \text { Internal Diameter } \\ \text { LWO } & \text { Liquid Waste Organization } \\ \text { NCSA/NCSE } & \text { Nuclear Criticality Safety Analysis/Evaluation } \\ \text { PTZ } & \text { pan-tilt-zoom } \\ \text { SRNL } & \text { Savannah River National Laboratory }\end{array}$




\subsection{INTRODUCTION AND BACKGROUND}

During a routine inspection of the $2 \mathrm{H}$ Evaporator pot in September 2007, significant waste buildup was observed on the evaporator surfaces. An estimate of the mass of the waste buildup indicated that chemical cleaning of the pot would be necessary during the spring of 2008 to meet the requirements of the Nuclear Criticality Safety Analysis/Evaluation (NCSA/NCSE). Before chemical cleaning is performed, LWO requested that two solids samples be obtained from the pot and analyzed for concentrations of materials that could cause criticality. The samples must be taken from two distinct locations within the pot. In November 2007, SRNL was given the formal request to design and fabricate samplers to obtain these solids samples. A sizeable accumulation of waste was observed between the upper portion of the warming coil piping on the side of the pot opposite the 3" internal diameter inspection riser that is used for sampling (see Figures 1 \& 2). While a sample from this specific location was not required for NCSA/NCSE purposes, this sample could provide valuable information for chemical cleaning and minimization of scale growth in the future. 


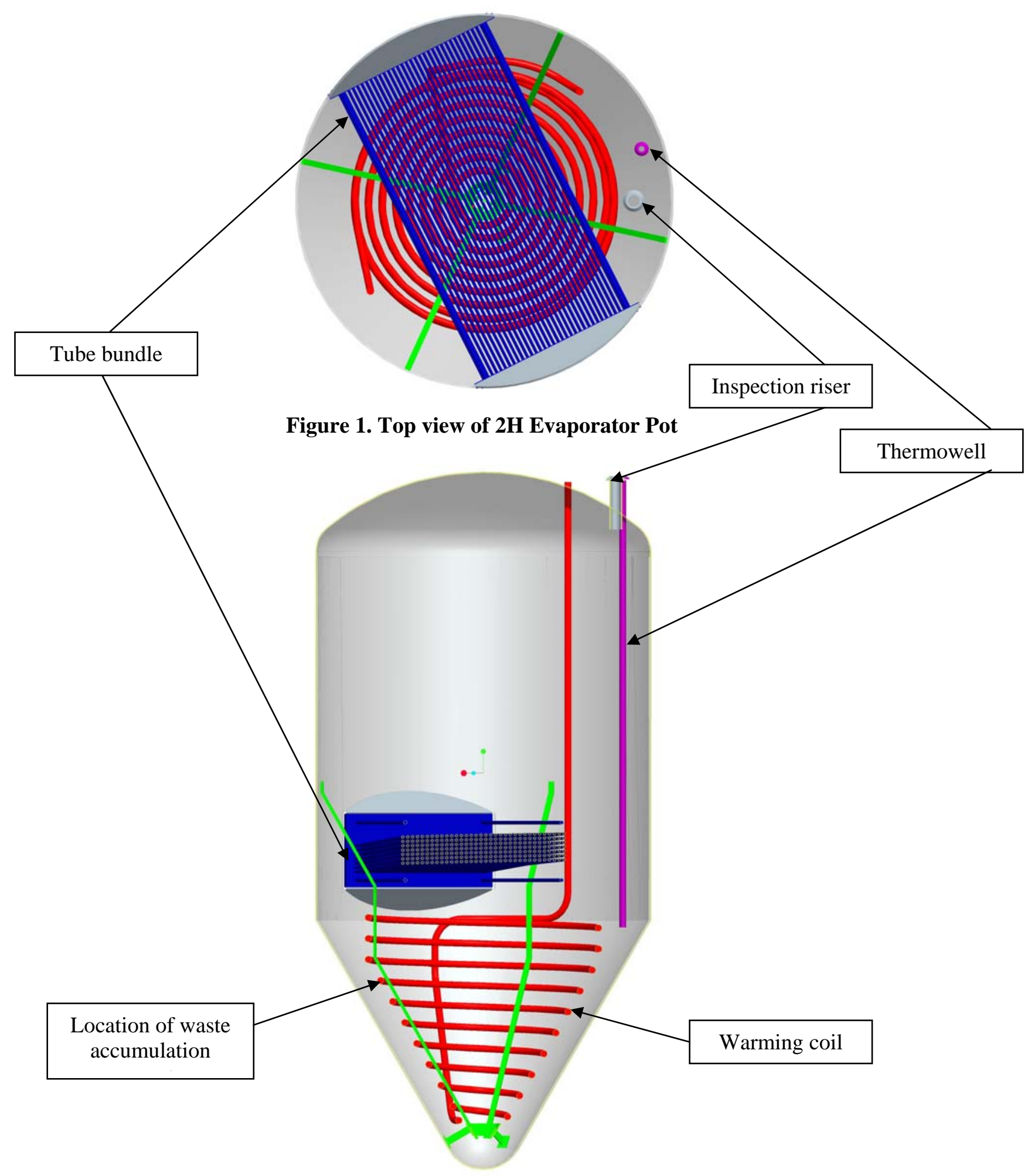

Figure 2. Cross section of $2 \mathrm{H}$ Evaporator through inspection riser (nozzle B) 
WSRC-STI-2008-00192

\subsection{SAMPLING TOOL DESIGN}

Since a sample was desired from the warming coil accumulation, a tool with multiple end-effectors was developed to obtain a sample from this location. During previous sampling evolutions in $2 \mathrm{H}$ Evaporator, some but not all of the tools developed successfully obtained samples. Several of the factors that contributed to prior failures include: the physical characteristics of the waste are not known, the access size and location is limited to a single 3" ID riser and the conditions in the evaporator often change between the date of the inspection used for tool development and date of the deployment. Due to these risk factors, four samplers were developed to ensure that two samples could be obtained.

\subsection{Sampling Tools}

SRNL has extensive remote sampling experience, including previous sampling of $2 \mathrm{H}$ Evaporator. Use of previously developed sampling tools was considered during development of the sampling strategy. Sample was obtained from the tube bundle stay rod in 2006, but the September 2007 inspection revealed very little waste at this location. Sample has also been obtained multiple times from the conical portion of the evaporator wall directly below the inspection riser. Visibility at this location was limited, so the existence of waste accumulation there could not be determined. The consistency of the material was also unknown. Four tools were developed based on these observations. All of the tools were developed using 3-D modeling software, which is extremely helpful for visualization of the various applications.

\section{Sampling tool 1 (warming coil accumulation sampler):}

In order to access the warming coil accumulation, a tool was developed that had a mast with a pneumatically actuated arm that directed the sampling device toward the accumulation (see Figure 3). A pneumatic cylinder was used to extend the sampling device to reach the accumulation. This concept is similar to the Tank 5 snow bank sampler (ref. 2), so the technology and experience gained during that effort were used for this effort. Since the consistency of the accumulation is unknown, three end effectors were developed for retrieval of the sample:

1. A vial snapper sampler with stainless steel vials, which has been used successfully in multiple Tank Farms sampling applications in the past, was fabricated (see Figure 4).

2. A pneumatic drill with multiple drill bit options was modified with a sample cup made of stainless steel and polycarbonate that was designed to hang below the drill bit to capture sample. The sample cup was mounted on a spring loaded bracket to ensure that the cup was always resting against the accumulation while not impeding the progress of the drill bit (see Figure 5).

3. A pneumatic chisel outfitted with the same sample cup mechanism as the pneumatic drill (see Figure 5). 


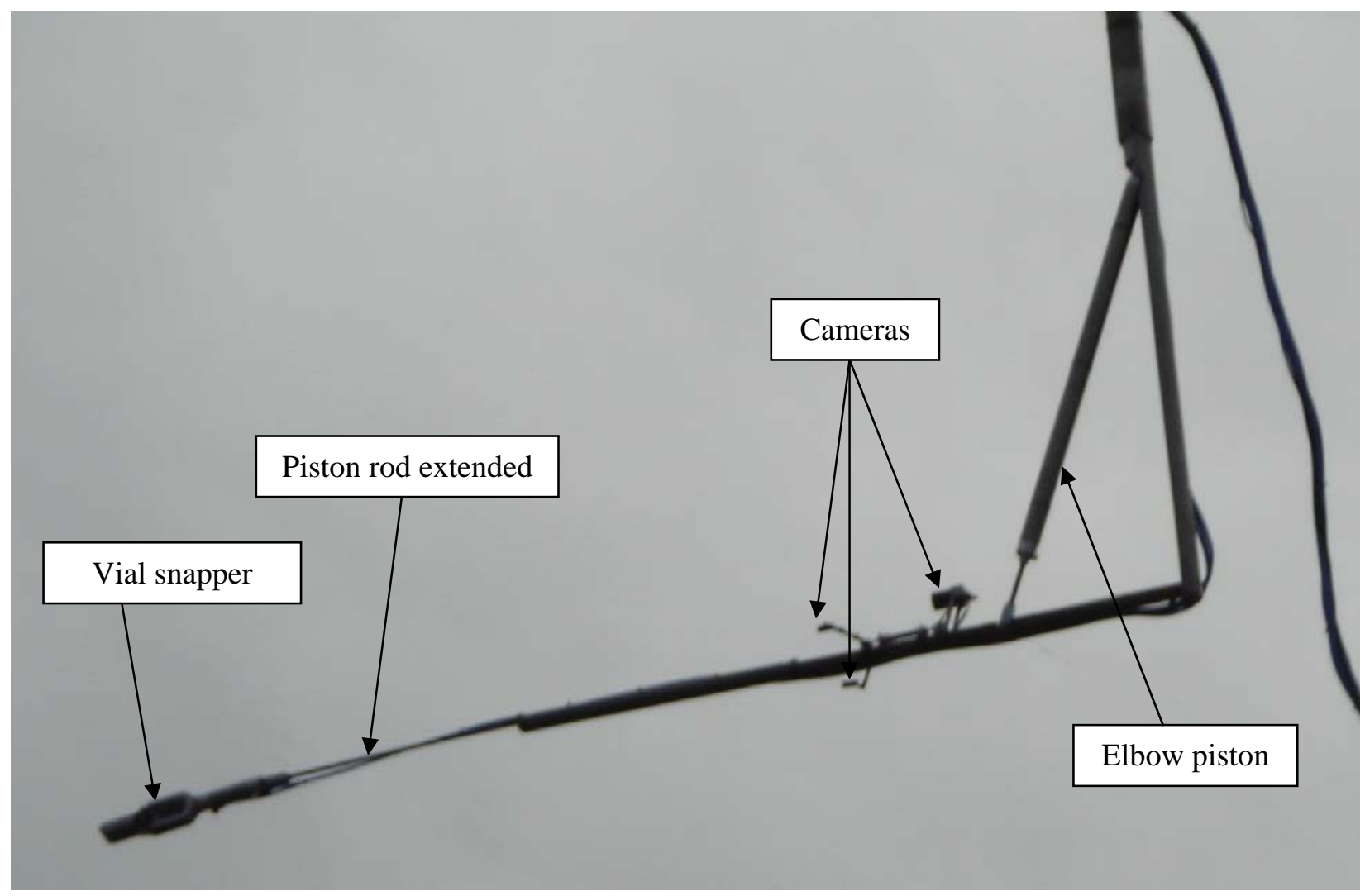

Figure 3. Warming coil accumulation sampler with vial snapper end effector

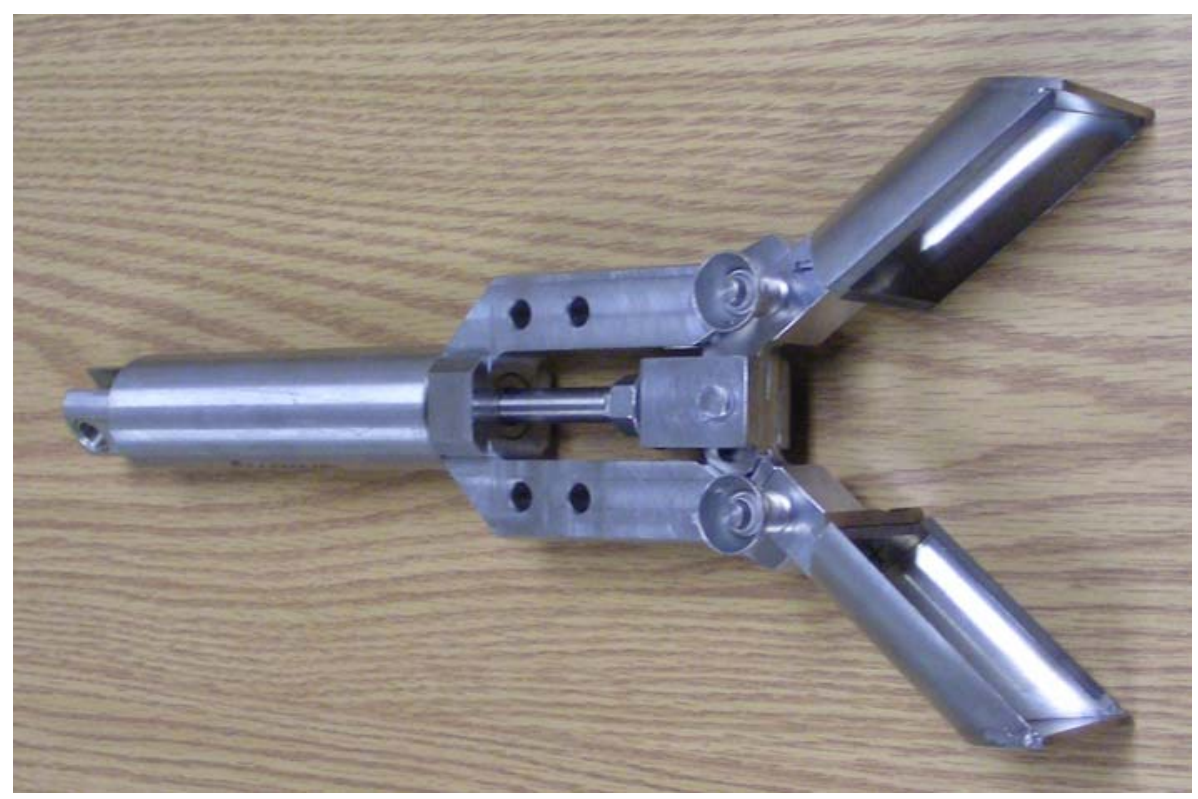

Figure 4. Vial snapper end effector for warming coil accumulation sampler 


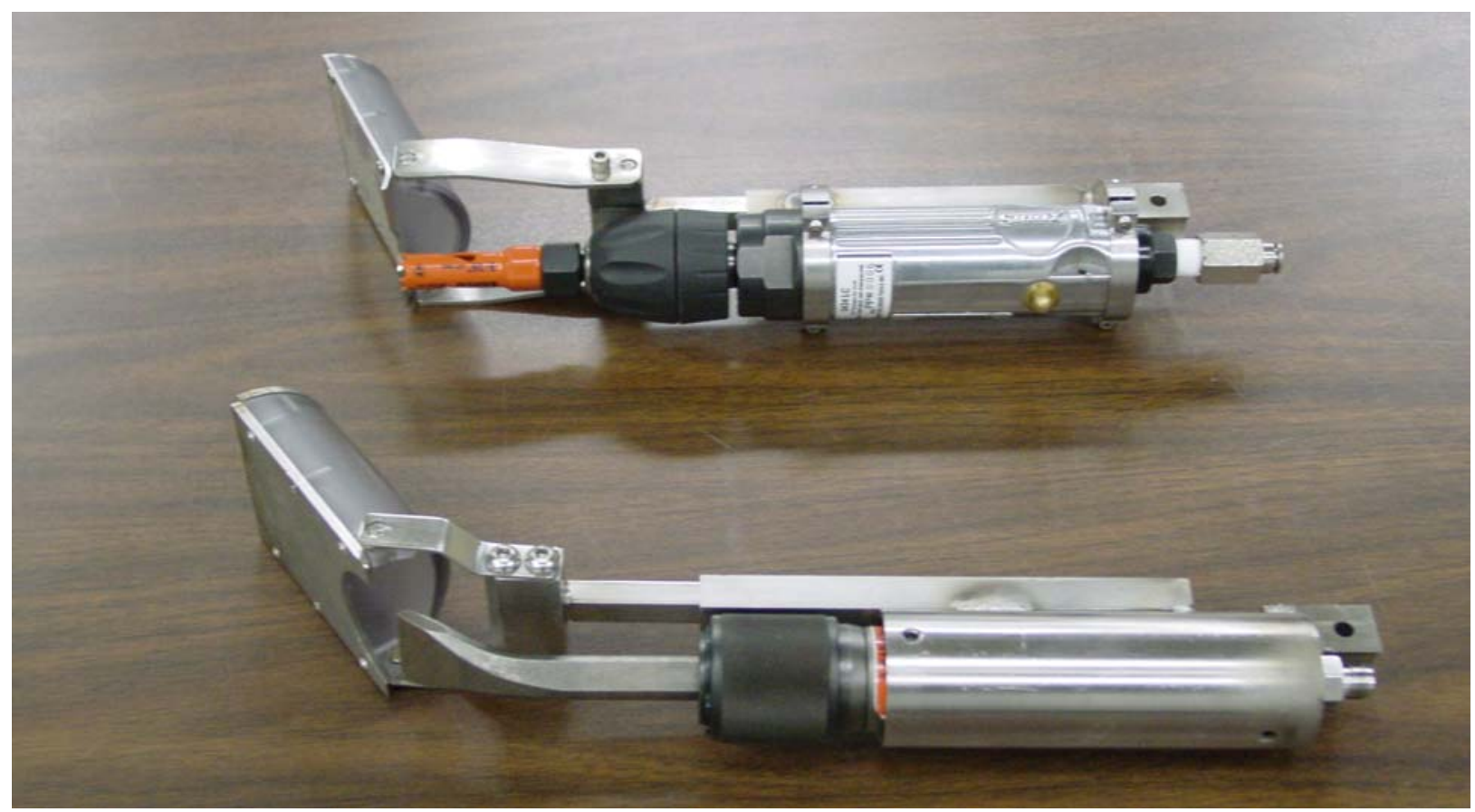

Figure 5. Drill \& chisel end effectors for warming coil accumulation sampler

Sampling tool 2 (wall scraper) \& sampling tool 3 (thermowell scraper):

During the September 2007 inspection of the pot, the readily accessible locations with the most waste buildup were on the pot wall slightly below the riser opening and on the evaporator thermowell. The pot wall and thermowell waste accumulations were near the entrance into the evaporator via the inspection riser. Samplers that obtain material from these locations require a shorter mast and allow sampler deployment personnel to use the riser as a reaction surface. These factors make these locations ideal for obtaining the samples desired. These two sampling locations were approximately the same distance from the inspection riser, so a single pneumatic deployment elbow was developed for deployment of both samplers (see Figure 6). In order to replace the wall scraper with the thermowell scraper, a single captured screw was unthreaded to release a scraper pivot mount from the deployment elbow (see Figure 7). Once the pivot mount was removed, the wall scraper could be removed and replaced with the thermowell scraper. Two stainless steel thermowell scrapers with different scraping angles and one wall scraper were developed (see Figure 8). The back sides of the scrapers were made of polycarbonate so that collection of samples could be viewed in real time. 


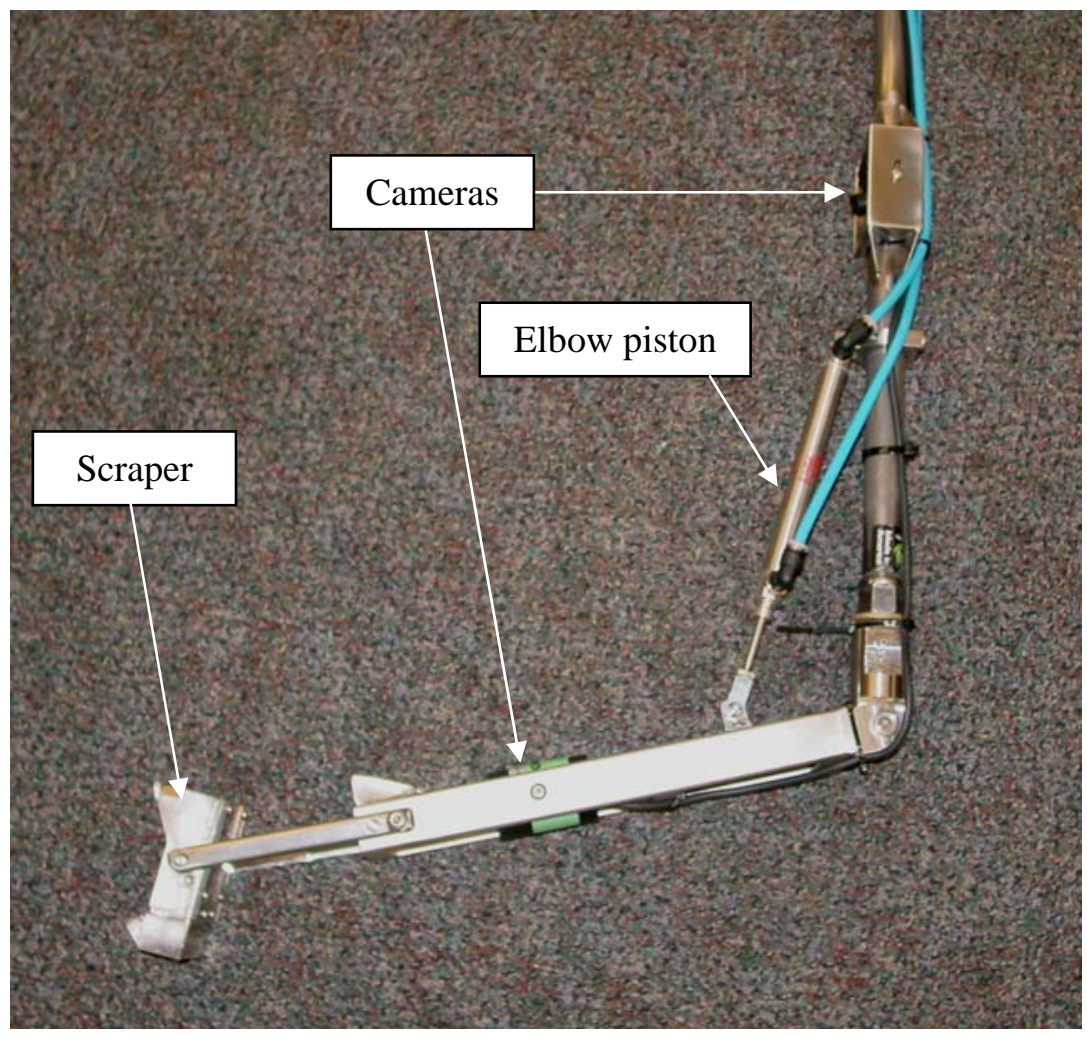

Figure 6. Elbow mechanism for wall scraper \& thermowell scraper

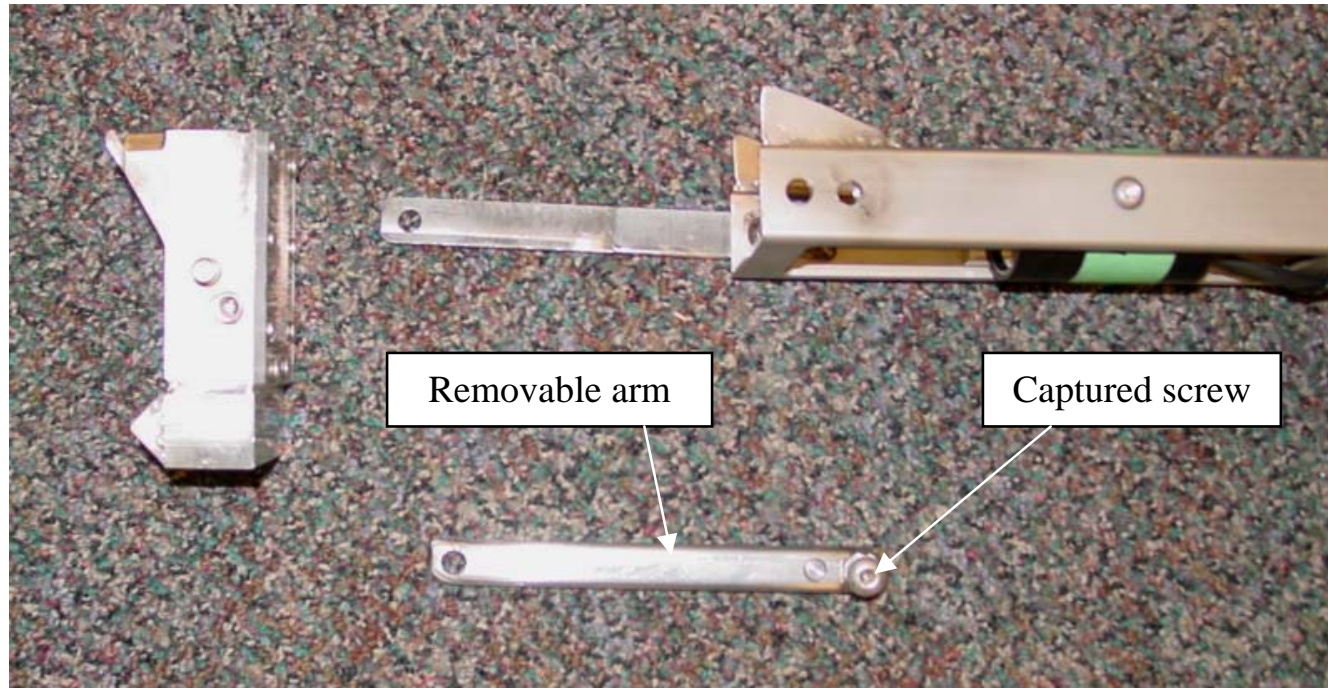

Figure 7. Wall scraper \& thermowell scraper- sample cup removal method 


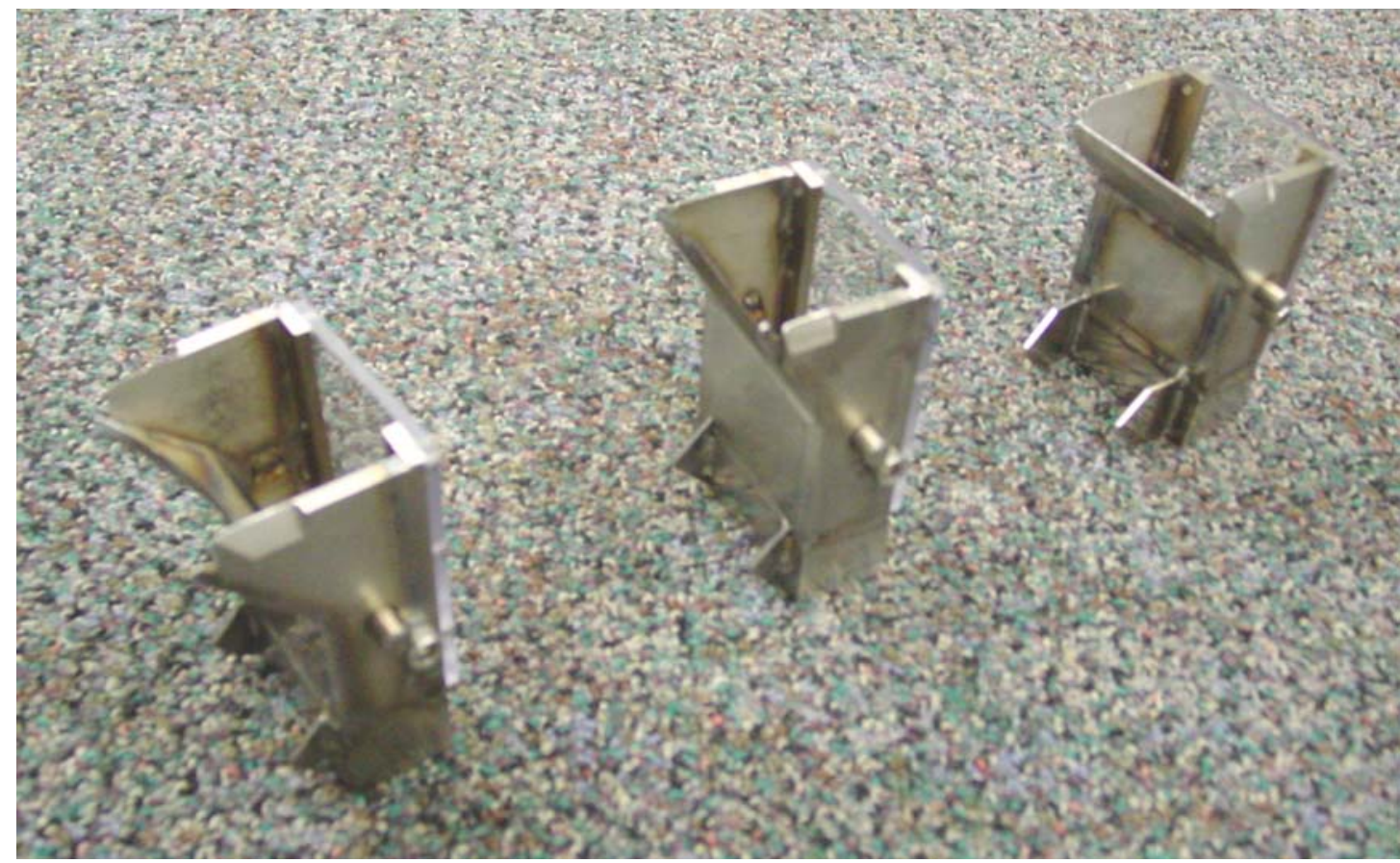

Figure 8. Right-left: $45^{\circ}$ thermowell, $30^{\circ}$ thermowell \& wall scrapers

\section{Sampling tool 4 (cone scraper):}

Visibility of the cone directly below the inspection riser was limited during the September 2007 pot inspection, so it was not known whether sample existed at this location. A sampler that scraped the cone wall has been successfully deployed in the past. Due to this previous success and the relatively low cost of fabrication, a stainless steel cone scraper was fabricated as a backup sampler (see Figure 9). The sampler was modified to include a polycarbonate window so that collection of sample could be viewed in real time.

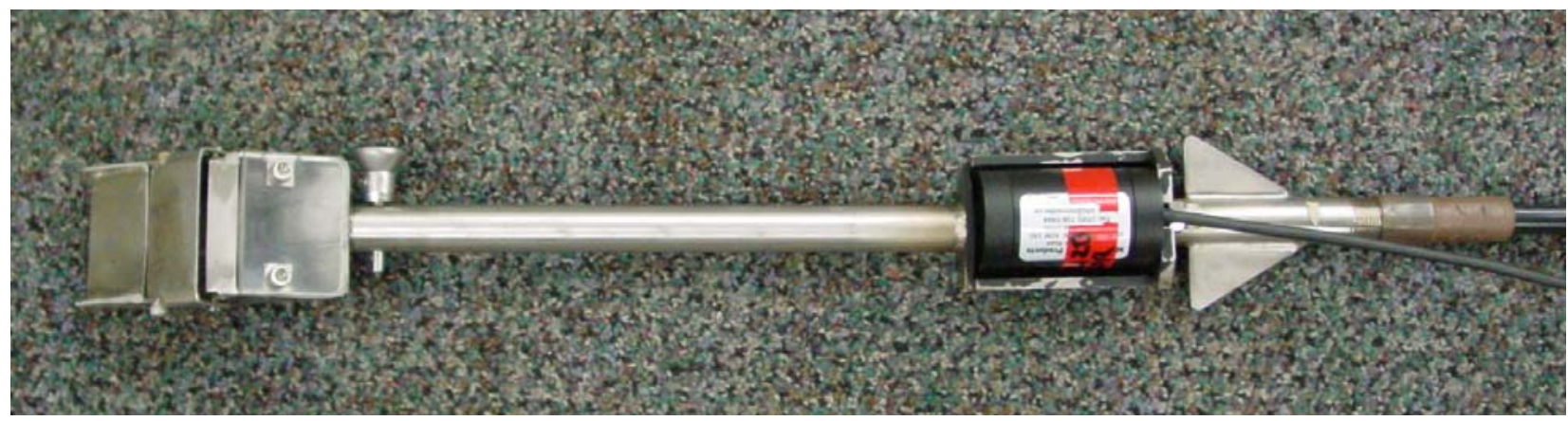

Figure 9. Cone scraper end effector

\subsection{TESTING}

\subsection{Warming coil accumulation sampler testing}

Because of the 3" access riser and all of the obstructions between the warming coil accumulation and the riser opening, a full-scale deployment mockup of the warming coil accumulation sampler was necessary. The mockup was performed in the Central Shops mockup evaporator, which is a full scale copy of the $2 \mathrm{H}$ Evaporator. The primary goals of the mockup were to ensure that the sampler would fit through the 3" access riser and that the sampler end effectors could reach the location of the warming coil accumulation. 
During 3-D modeling of the sampler, it was recognized that deployment of the arm would involve multiple iterations of lowering the entire mast following by raising the elbow in small angular increments. A pan-tilt-zoom (PTZ) camera was deployed through another riser and lowered below the tube bundle to witness rotation of the mast elbow and the location of the end effector. The sampling riser is the only riser available in $2 \mathrm{H}$ Evaporator, so this inspection angle is only available during mockups.

The sampler was successfully inserted into the Central Shops mockup evaporator. Once the sampler was lowered to the desired elevation and rotated in the desired direction, the elbow air cylinder was actuated. After the elbow was actuated, the arm raised farther than expected which caused the arm to leave the field of view of the PTZ camera. This may have been caused by inadequate flow control or a leaking air connection. The cameras located on the arm gave limited views of the location of the arm within the pot. Multiple attempts were made to raise and lower the elbow using the air cylinder. It was that the end effector was caught between the warming coil or another obstruction, so the entire mast was then raised to attempt to free the end effector. When this was not effective in freeing the sampler, the PTZ camera was raised to observe the sampling mast where it entered the evaporator. It then became apparent that the air cylinder had been bent and that the mast could not be retrieved without dismantling the sampler.

After review of the mockup video, it was postulated that the arm was raised while the air cylinder pivot was still in the access riser. This probably damaged the air cylinder just enough to prevent air cylinder actuation. After multiple attempts to actuate the cylinder using all of the options available, the mast was raised by the crane which probably caused the remainder of the air cylinder damage.

During development of the sampler, addition of a camera above the top elbow joint was determined to be necessary, but fabrication of this feature was postponed until after the mockup in order to meet the aggressive deployment schedule. Because multiple viewing angles were available in the mockup, use of this additional camera was not deemed necessary to perform the mockup. This feature was expected to be added along with any other needed improvements that were identified during the mockup.

The following items were reviewed in an effort to determine the cause of the air cylinder damage that happened during the mockup. The 3-D model of the sampling tool was placed in the 3-D model of the evaporator to determine whether enough room was available for raising the arm. The 3-D model indicated that approximately 12" of height clearance was available. The design length of the access riser was compared with the length of the riser in the 3-D model and found that the riser in the 3-D model was approximately 6" shorter than the $2 \mathrm{H}$ Evaporator design drawings. This reduces the clearance to $6 "$. The 3-D model of the evaporator was made for visualization of the pelican sampler deployment two years ago. The length of the access riser was not critical for this application. It is also possible that the mockup evaporator access riser is actually longer than the designed length because this is not a critical dimension for most inspections. All of these factors led to very little margin for error with no visibility at the riser access.

\subsection{Wall scraper, thermowell scraper and cone scraper testing}

After the testing in Central Shops was complete, the decision was made to continue toward sampling Evaporator $2 \mathrm{H}$ with the remaining three tools. Because these tools were obtaining samples from much more accessible areas than the warming coil accumulation sampler, the plan had always been to not test these tools within the mockup evaporator. Instead, the ability of the tools to fit through a 3" riser and scrape simulant material off of a mockup surface were tested in the 723-A high bay. The mockup configurations with plaster of Paris simulant are shown in Figures 10 and 11. Plaster of Paris was used because it has proven to be a representative mechanical simulant of $2 \mathrm{H}$ Evaporator scale during past sampling evolutions. Since the diameter of the evaporator wall is 8' and the cone scraper obtains sample at a cone diameter of nearly 8', the minimal curvature encountered by the wall scraper and cone scraper are approximated by a flat plate surface. Not shown in Figure 10 is the 10' long 3" schedule 40 pipe that 
is a mockup of the access riser. The cone mockup is placed on the floor directly below the wall/thermowell mockup at approximately the correct vertical distance from the access riser.

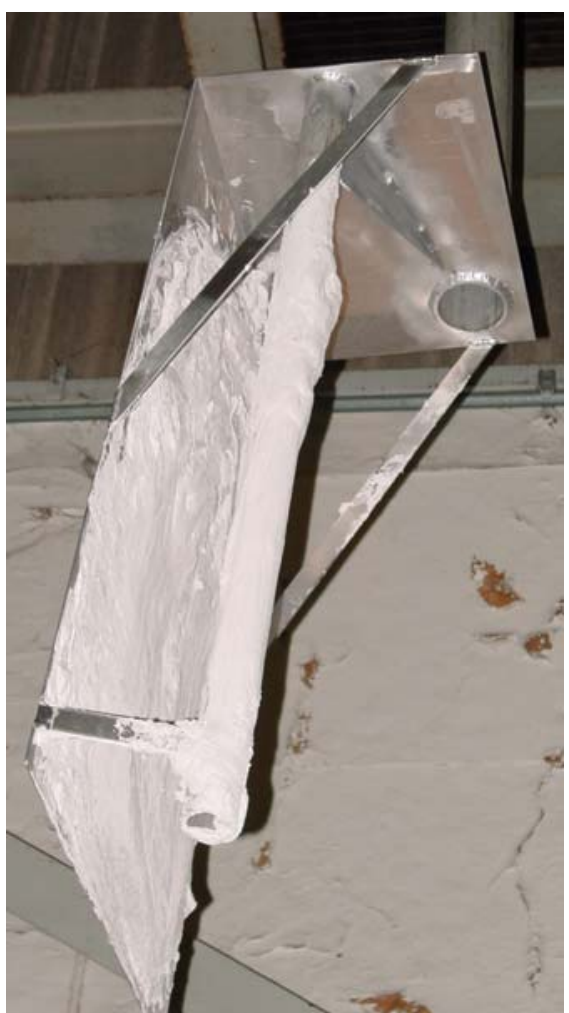

Figure 10. Wall \& thermowell mockup

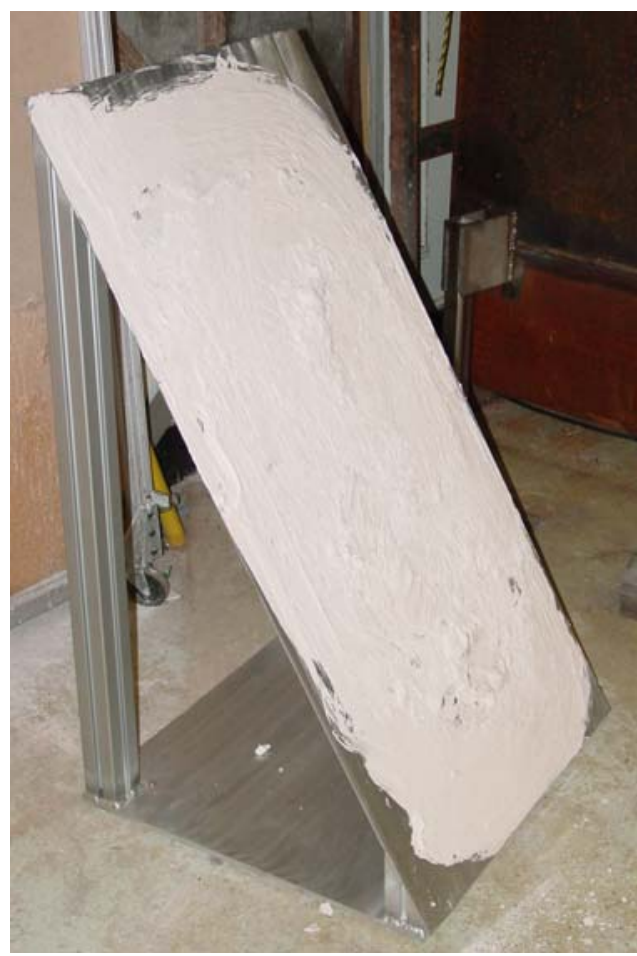

Figure 11. Cone mockup 
WSRC-STI-2008-00192

Testing of the wall and thermowell scrapers proved that the scrapers were capable of obtaining simulant from the desired sampling locations. The plaster of Paris simulant proved to be a conservative simulant, in that it was more difficult to obtain a simulant sample than the actual material in $2 \mathrm{H}$ Evaporator. The results of the testing showed:

- The insulation of one of the camera cables was damaged by wear against the bottom edge of the access riser. This occurred during the scraping process because the mast uses the access riser as a reaction surface when the elbow is deployed. The camera was replaced and the problem was resolved by rerouting the cable so that it would not get pinched between the mast and the bottom edge of the access riser. This lesson is valuable for cable and hose management of all tools that may use an access riser as a reaction surface.

- A rotational stop was needed to limit rotation of the scrapers to the desired orientations. Addition of the stop enhanced scraping efficiency and minimized the risk of the scrapers rotating to an upside down position and dumping a sample.

- A greater understanding of the pneumatic controls was obtained. A four-way, three-position, closedcenter, spring-return control valve was used to direct air flow to the elbow cylinder. It was found that flow control is needed in both the discharge and exhaust directions for more precise control. Needle valves were installed on both discharge ports and both exhaust ports and were set to allow minimal flow. This configuration allowed rotation of the elbow to various angles with moderate control. It is believed that greater control could be gained using a larger diameter air cylinder. The small diameter cylinder that was used was easily overcome by the weight of the sampler so that when the control valve was held open too long to lower the sampler, the scraper would quickly drop and rebound at the bottom of the elbow's stroke. A larger diameter cylinder would also be more forgiving because the same flow will cause the cylinder piston to move less distance.

The cone scraper design had successfully obtained material from the 2H Evaporator pot during the 2006 sampling evolution. The scraper was tested to ensure that it fit the through the 3" diameter access riser and to verify its scraping capability. No problems were observed during testing.

After the samplers were tested, an operational mockup was performed with Tank Farms personnel in attendance. The scrapers have sharp edges to enhance their scraping ability. The wall scraper and thermowell scraper blades protrude and Tank Farms personnel expressed concern about the possibility of puncturing the glove bag during deployment. To address this concern for the wall scraper and thermowell scraper, the sharp corners of these scrapers were dulled. The cone scraper blade does not have a protruding blade, so it was not modified. In addition, lidded cups for holding the wall scraper and the thermowell scraper during handling, sleeving and transportation were designed and fabricated on a rapid prototype machine using ABS plastic. (see Figures 12 and 13). 


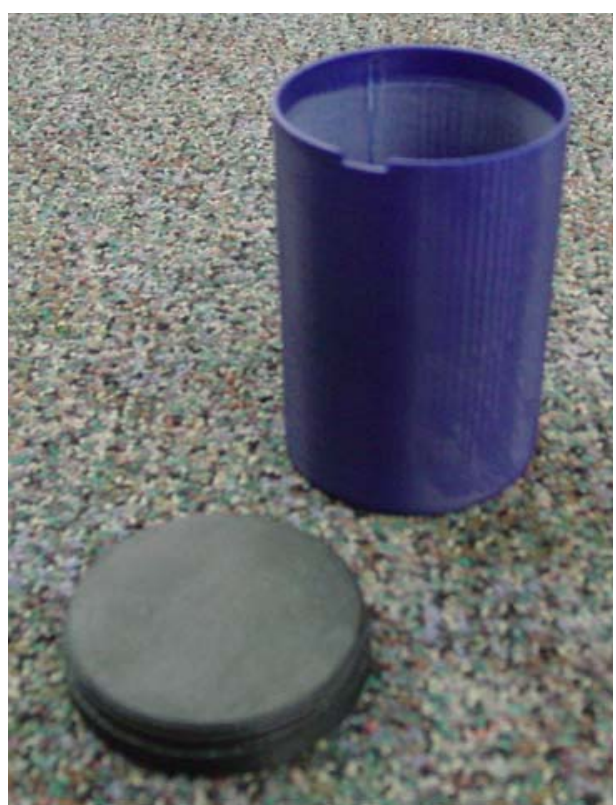

Figure 12. Scraper container with lid removed

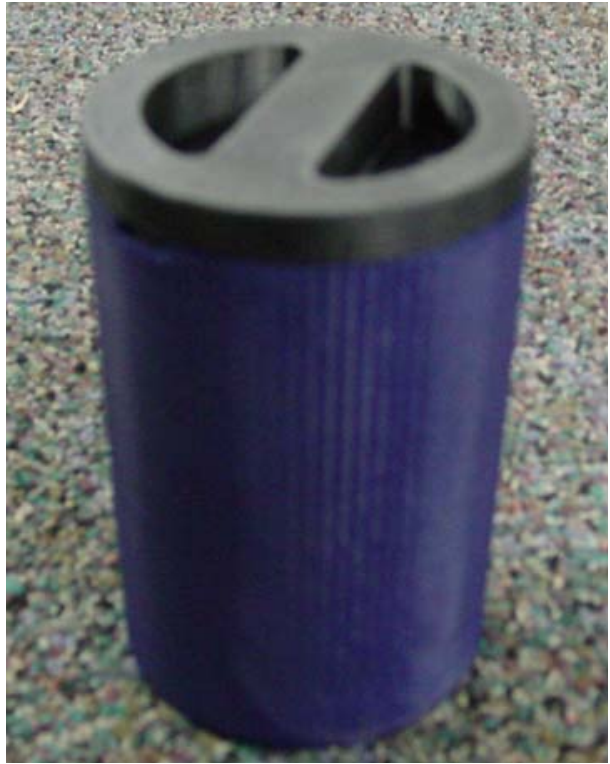

Figure 13. Scraper container with lid installed

\subsection{DEPLOYMENT}

Three locations were sampled inside the Evaporator. All three locations were accessed through the inspection port of the $2 \mathrm{H}$ Evaporator which is a vertical access port made of 3 inch schedule 40 pipe. The area of staging and deployment surrounding the inspection port was a Contamination Area (CA).

A glove bag (see Figure 14) was used as a containment unit to prevent the spread of contamination. The glove bag consisted of many access ports and glove ports to allow equipment/samples to be sleeved in/out and personnel to handle equipment/samples. All equipment and tools were pre-staged inside the glove bag. After the inspection port cover was removed the glove bag was carefully placed over the opening and a tape seal was formed around the port extension. A section of aluminum 5" pipe was used 
to guide installation of the samplers and as a resting place for the mast clamp (to be discussed later). Next, the samplers' support lines such as electrical power, air supply, and video were attached to electrical receptacles, air compressor, and monitors/recorders. A portable compressor supplied by SRNL was used as the air supply. The video signals were split off to two video goggles (see Figure 15) for the sampler operators and to the camera inspection van where LWO Engineering could provide input for the sampling evolution.

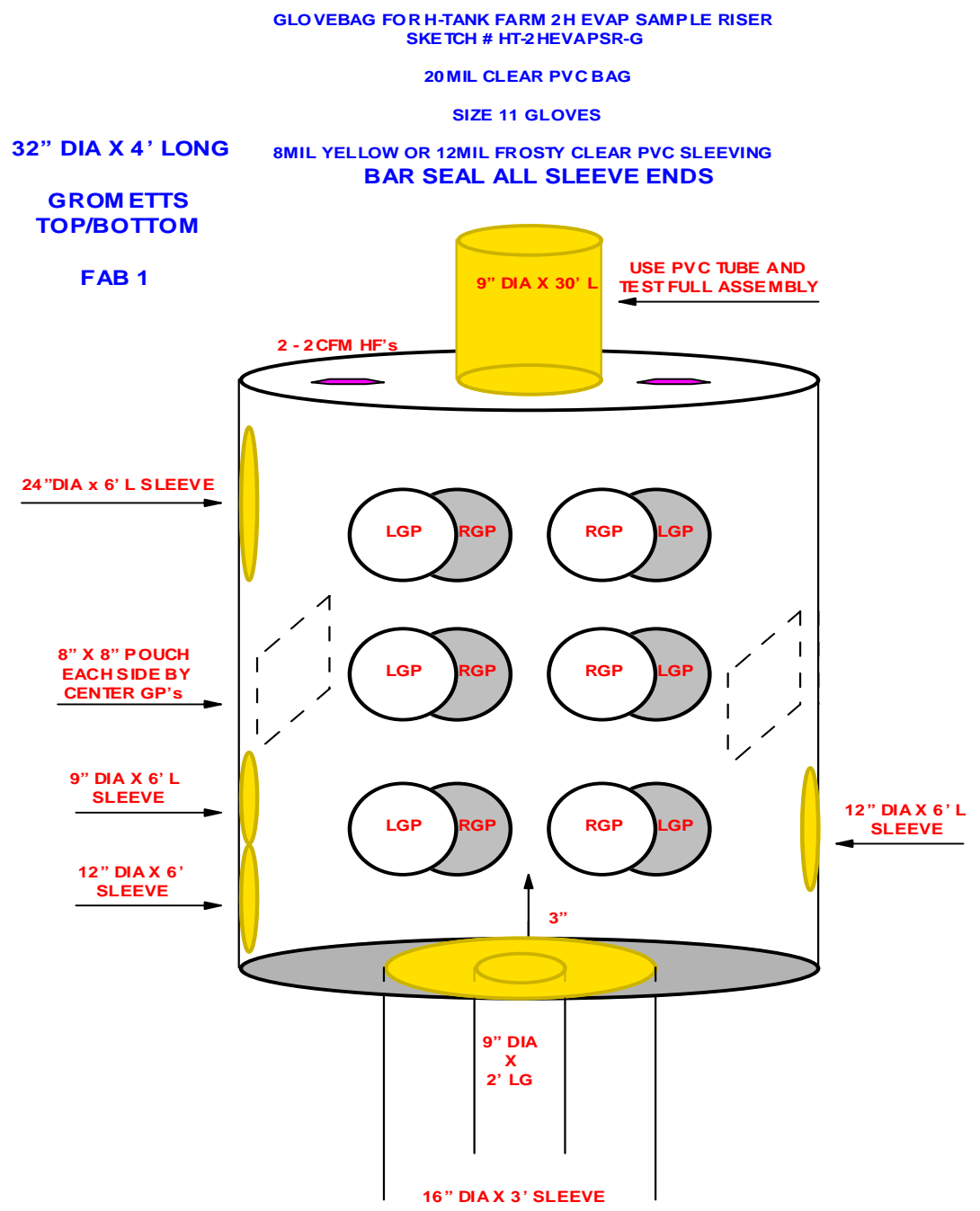

Figure 14. Glove bag used during sampling

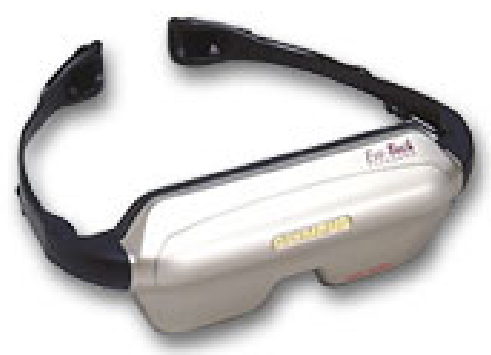

Figure 15. Video goggles used during operation of sampling equipment 


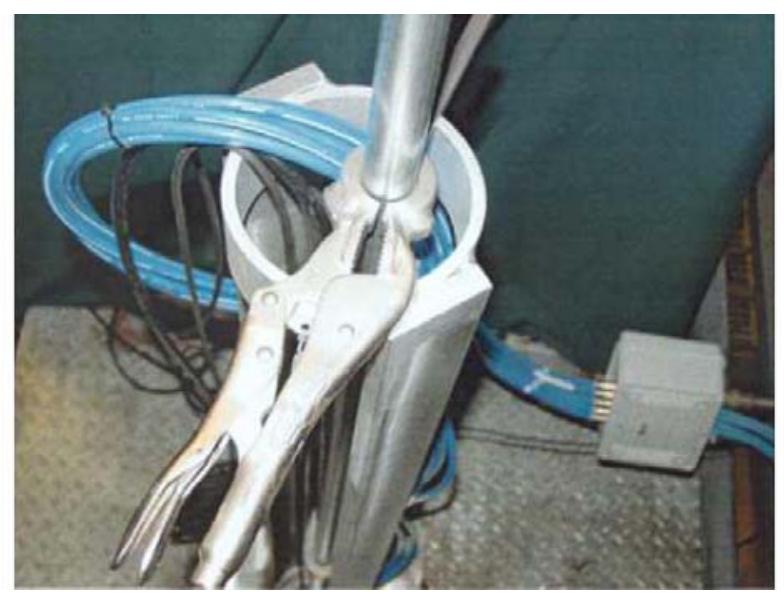

Figure 16. Sampler mast clamp

The first location to be sampled was the material on the wall. This was attempted first because it was the dry location that was deemed the least difficult to be sampled. The wall scraper was assembled and deployed by three people utilizing the various glove ports as needed. The wall sampler's mast was joined a section at a time by threading the steel poles together. A clamp (see Figure 16) was used to secure the mast to allow operators to rest and free up their hands to perform other tasks during deployment/retrieval. The wall sampler's top view camera was used to determine that the tool was sufficiently below the inspection port's riser (see Figure 18). With the sampler clear of the riser opening at the bottom of the port, the sampler was lowered an additional three feet to allow for the stroke needed for the sampler to scrape the wall for a sample. Next, the sampler was slightly actuated to lift the end-effector arm. Utilizing the camera on the arm, the sampler operator was able to locate the wall and orientate the sampler towards it. Then, the sampler sample cup was fully actuated against the wall surface and the first scrape stroke was taken. The arm camera provided confirmation that material became detached from the wall surface and fell into the cup (see Figures $17 \& 19$ ). The arm camera also provided a view inside the cup via the clear polycarbonate backside. Finally, the sampler was slowly deactuated, allowing the sampler cup to detach from the wall. The sampler was lowered and additional scrapes were performed until adequate sample was obtained.

The second location to be sampled was the thermowell. The thermowell sampler and the wall sampler are essentially the same tool, but with a different end effector sample cup. The scraping edge on the thermowell sampler cup is a curved edge which accommodates the curve of the 1-1/2" diameter thermowell. With the two samplers being similar, the deployment of the thermowell sampler was nearly identical. The sampler was deployed and material was collected.

The wall and thermowell scraper sample cups were attached in the same manner. In both sampling cases, the mast sections were dismantled during retrieval of the samples. When the sampling cup reached above the port opening, a cardboard square was put on top to prevent items from dropping into the evaporator. A pair of channel locks was used to hold the sample cup. Then, a sample holder was put underneath to hold the sampling cup when it was detached by loosening the button head socket screw on the side bar. The sampler holder's purpose was to protect the sleeving from the sample cup's sharp edges. Once this side bar was detached, the sample cup was placed into the sample holder and the sampler holder lid was installed by pushing it down until sealed. At this point, the sample holder with the sample cup inside is sent down an available glove bag port and sleeved out to be put into a depleted uranium doorstop for transportation. 


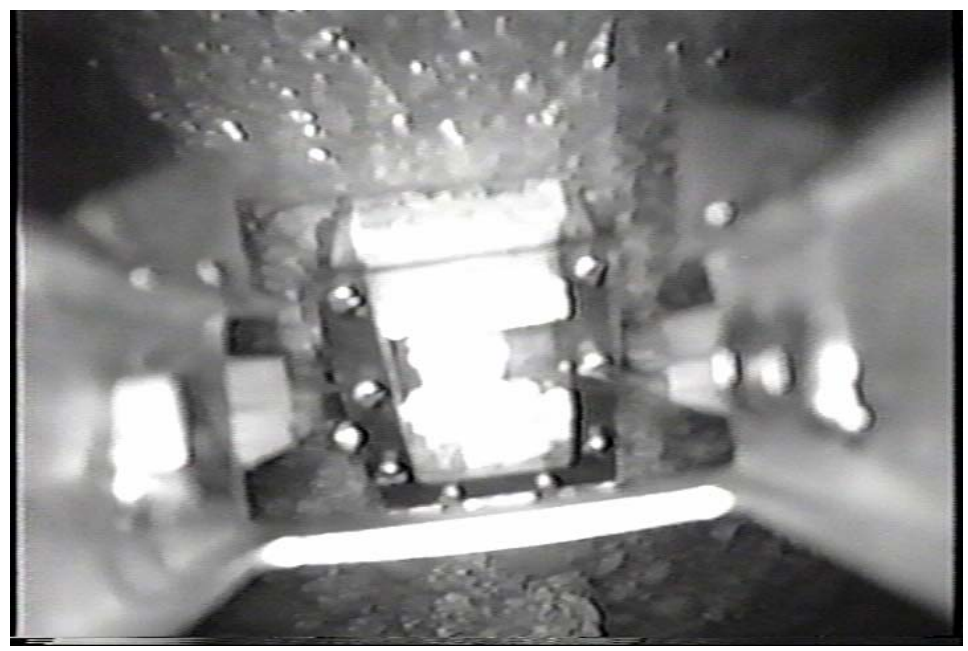

Figure 17. Scraping the evaporator pot wall, arm camera view

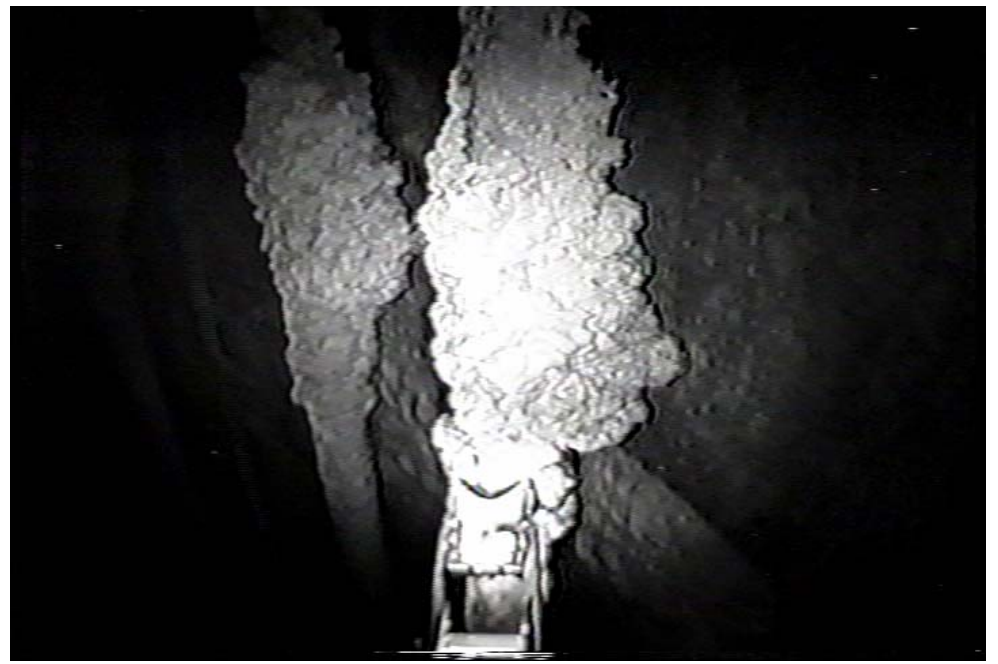

Figure 18. Scraping the thermowell, mast camera view

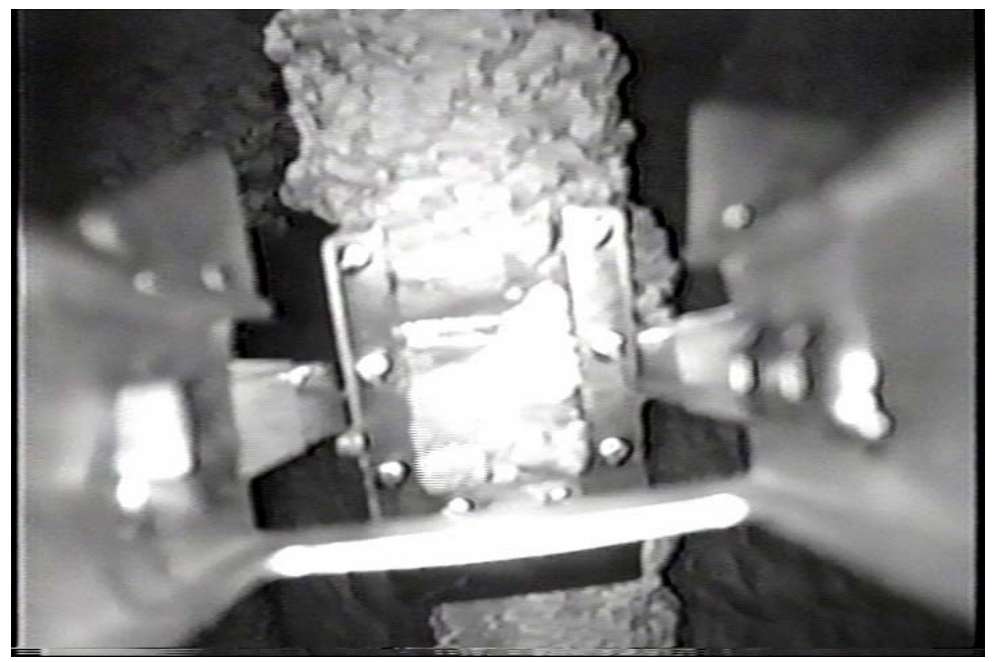

Figure 19. Scraping the thermowell, arm camera view 
The third and final location that was sampled was the cone portion of the evaporator directly below the inspection port riser. The cone sampler has one camera inline with the deployment mast and no moving parts. This sampler required one operator during the actual scraping portion of the sampling. As with the wall and thermowell sampler, the cone sampler was deployed by joining a series of threaded poles. Sections of the mast were assembled to reach the pot. Additional sections were then attached to provide the needed stroke for scraping. The cone sampler move moved vertically up and down to "scrape" the cone's interior surface with the cone sampler end-effector sample cup which has a sharp edge springloaded that pressed against the cone surface. The sampler was jogged repeatedly to scrape material into the sample cup. The stroke of the scraping included some section of the cone below the liquid level. At times, both the sampler cup and camera were submerged (see Figure 20). It was difficult to confirm how much material was obtained even though there was a polycarbonate cover to allow viewing into the top of the sample cup. The light caused glare from the polycarbonate cover, which hindered the view as well. Liquid on the camera lens compounded the poor visibility. Liquid Waste Organization (LWO) Engineering concurred with SRNL that sufficient material was likely collected and additional scraping was not necessary.

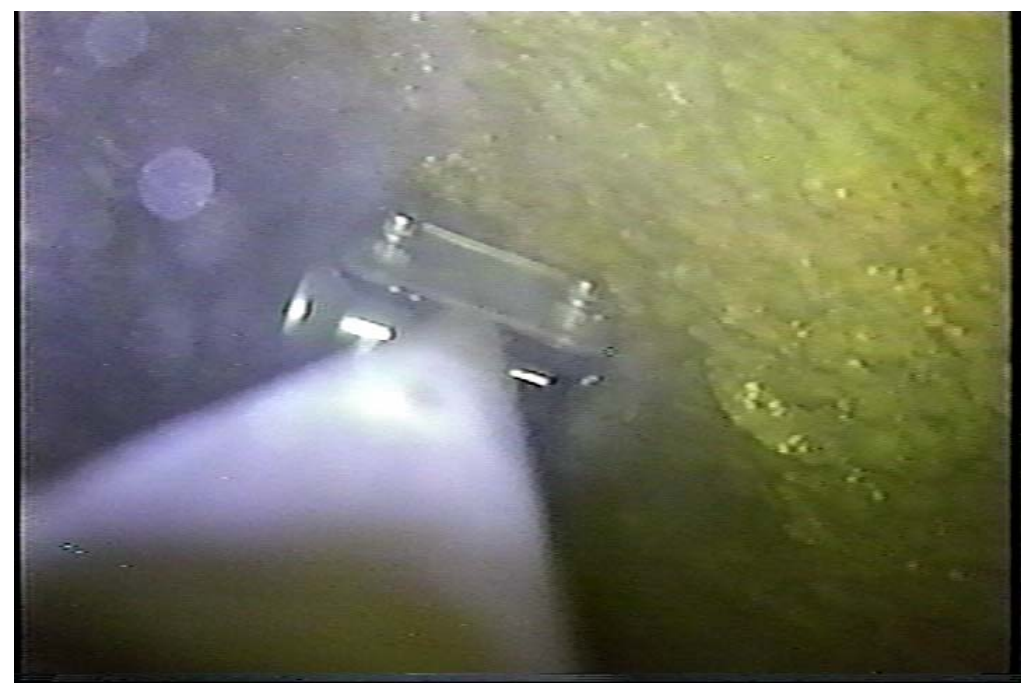

Figure 20. Scraping the cone, scraper \& camera submerged

The cone sampler cup was attached to the sampling mast with a quick disconnect pin. When the sampling cup reached above the port opening, a cardboard square was put on top to prevent items from dropping into the evaporator. The sampler cup was held with a pair of channel locks and the pin was removed to release the cup from the sampling mast. Next, the sample holder with the sample cup inside was sent down an available glove bag port and sleeved out to be put into a uranium doorstop for transportation.

\subsection{SHIPMENT AND UNLOADING OF SAMPLES FOR ANALYSIS}

The samples were transported to the SRNL shielded cells in three separate uranium doorstop shipping containers. The wall scraper and thermowell scraper were both placed in the rapid prototyped scraper containers and sleeved out prior to shipment. The sleeves were 3" diameter sleeves designed specifically for packaging the samples for shipment. A separate sleeve was used for each sample so that only one Bline cut was necessary to seal the package.

No problems were encountered during unloading of the samples in the SRNL shielded cells. Figures 21, 22 and 23 show the samples that were recovered from the sampling vials. 


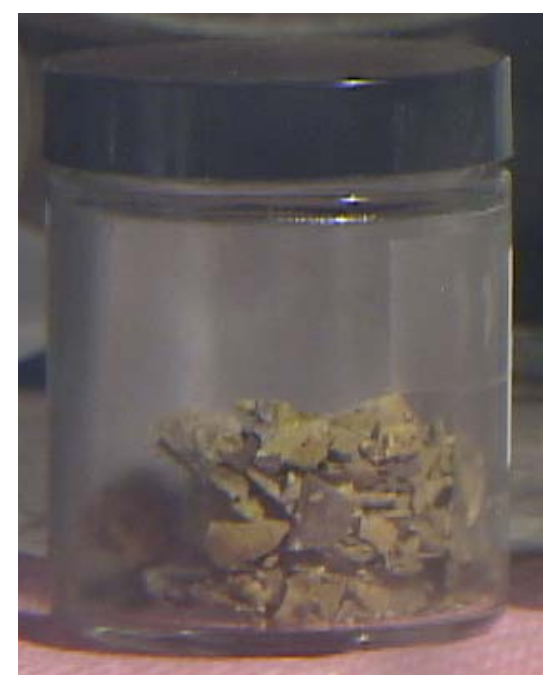

Figure 21. Wall sample recovered for analysis (HTF-08-28)

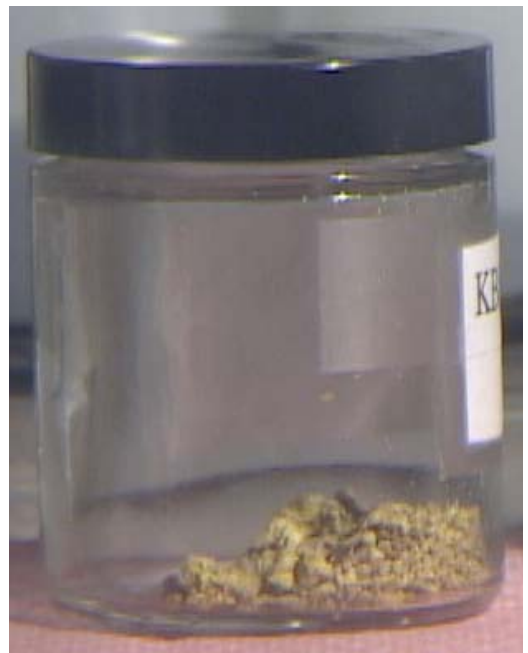

Figure 22. Feed line sample recovered for analysis (HTF-08-29)

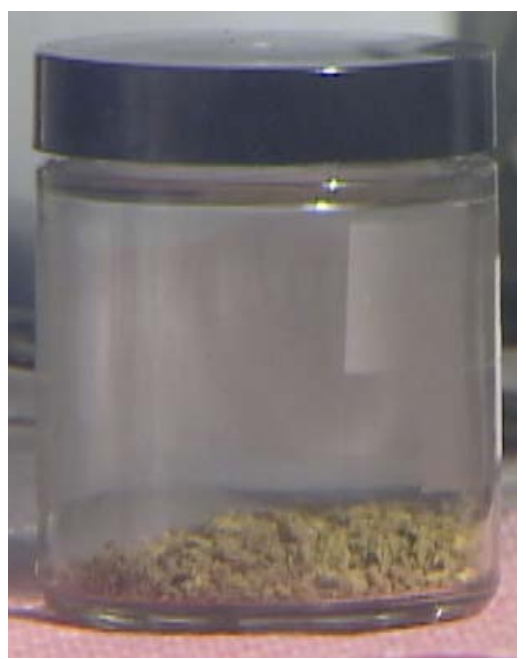

Figure 23. Cone sample recovered for analysis (HTF-08-30) 


\subsection{LESSONS LEARNED AND SUGGESTED IMPROVEMENTS}

During the sampling evolution, there were areas where lessons learned and suggested improvements could be noted. The first item is the glove bag. Suggested improvement for the bag is to increase the height to better facilitate the mast sections. In addition, the number, size and location of access ports/sleeving should be changed to accommodate the number of samples and size of equipment to be sleeved and to reduce congestion when glove ports are being used. Figure 24 shows the proposed improvements.

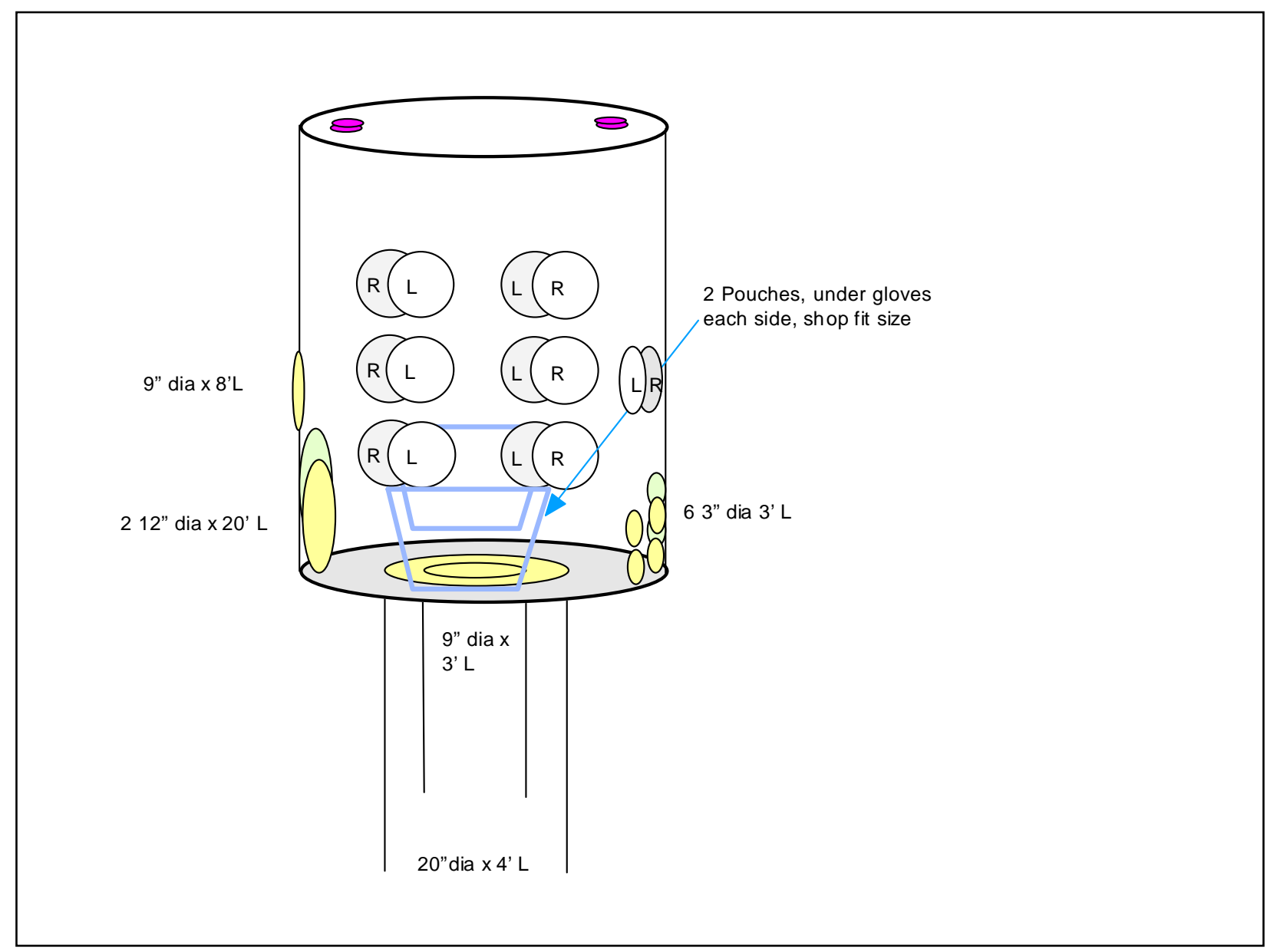

Figure 24. Improved glove bag for future deployments

Cable maintenance is an area where improvements could be achieved. The wall scraper and the thermowell scraper had air lines for the air cylinder, power cables for cameras/goggles, and signal cable for video. This posed a risk of tangling the wire on equipment within the evaporator. One possible improvement would be development of an integrated station that includes an air line manifold, a power strip and video signal connections. Battery powered video goggles would eliminate the need for some wires. During deployment of the cone scraper, the camera cable would become slack on occasion and dangle below the sampler. This problem could be eliminated by assigning a dedicated operator to keep slack out of the video cable that is in the evaporator pot during deployment.

The mast clamp, which is a modified vise grip, loosened and had to be retightened on occasion so that it would properly clamp on the deployment mast. The adjustment mechanism could be tack welded in the 
correct location for optimal clamping. If this modification is implemented, the clamp must be tested on all of the mast poles before deployment since there may be variability in the outer diameters of the poles.

The large accumulation of waste on the thermowell presented a specific operational challenge. The scraper got stuck on this accumulation so that too much air had to be relieved from the air cylinder to retract the arm. This caused the arm to flop downward when it released from the thermowell, which in turn ejected the sample from the scraper vial. Fortunately, additional sample was obtained. Additional practice is needed to ensure this situation does not occur in the future. It is probable that lifting the scraper after relieving a small amount of air pressure would straighten the arm enough to release it from the thermowell. In order to use this method, the sampler must be deployed at a low enough point. The distance the mast must be raised to release the elbow must be determined by testing.

Due to the schedule restraints of this job, SRNL personnel operated the equipment in the glove bag. We were not aware of glove bag specific training until the sampler deployment pre-job brief. This training had to be taken before the job could be performed. For any job that requires SRNL personnel to deploy equipment, the training authorities in the specific facilities should be consulted early in the development stage to ensure that no additional training is required to support the job.

Having multiple camera views contributed greatly to the success of the wall scraper and thermowell scraper. Both cameras were useful for locating the desired sampling location. The arm-mounted camera identified whether adequate sample was taken. Once the mast-mounted camera had visibility within the pot, the operators knew that it was safe to actuate the elbow. This eliminated that possibility of making the same mistake that was made during the Central Shops mockup. Integration of multiple camera angles into the design of the tools is very important to the success of remote deployments.

\subsection{ACKNOWLEDGEMENTS}

In order to complete this job in a very compressed schedule, a concerted team effort was required.

Success would not have been possible without the contribution of the following people:

SRNL Engineering:

Dan Krementz, William Cheng, Montenius Collins, Mike Dalmaso, Monica Hall

SRNL Machine Shops:

Tommy McCoy, Micah Boylston, Mike Stowell, 723-A Machine Shop, 749-A Machine Shop

SRNL I\&E Personnel:

Joe Wilson, Dennis Faglier

SRNL Designers:

Ken Meeler, Larry Feutral, Garry Glazener

SRNL Support Staff:

Jim Buchanan, Nate Miller, David Silver

LWO Engineering, Operations, and Maintenance:

Willie Simon, Terry Allen, Danny Schaffer, Frank Simonetti and numerous others who assisted with sampling or worked behind the scenes. 


\subsection{REFERENCES}

1. Allen, T. L., Technical Assistance Request to Develop 2H Evaporator Samplers. 2008-LWOTF002, Savannah River Site, Aiken, SC 29808 (2007).

2. Cheng, W. Y., Nance, T. A., Vrettos, N. J., Tank 5 Sampling. WSRC-STI-2007-00654, Savannah River Site.

3. Krementz, D., Hazard Analysis Package for $2 \mathrm{H}$ Evaporator Pot Sampling Testing/Demonstration, SRNL-RSE-2007-00095, Savannah River Site, Aiken, SC 29808 (2007).

4. Krementz, D., Task Technical Plan for 2H Evaporator Sampling. WSRC-RP-2007-01283, Savannah River Site, Aiken, SC 29808 (2007). 
Distribution:

T. L. Allen, 241-121H

D. C. Blair, 704-8H

M. L. Boylston, 723-A

J. D. Buchanan, 723-A

W. Y. Cheng, 723-A

H. W. Coleman, 773-A

M. Collins, 773-A

M. J. Dalmaso, 723-A

D. P. Faglier, 773-A

A. P. Fellinger, 730-A

L. E. Feutral, 730-A

F. F. Foster, 730-A

E. J. Freed, 704-56H

G. R. Glazener, 730-A

J. C. Griffin, 773-A

M. C. Hall, 773-A

D. Krementz, 723-A

S. L. Marra, 773-A

D. J. Martin, 703-H

F. T. McCoy, 723-A

K. T. Meeler, 730-A

N. Miller, 723-A

T. A. Nance, 773-42A

R. L. Salizzoni, 703-H

D. O. Schaffer, $241-2 \mathrm{H}$

D. M. Silver, 773-A

W. E. Simon, 704-56H

F. A. Simonetti, 241-57H

M. S. Stowell, 749-A

A. J. Tisler, 773-A

N. J. Vrettos, 723-A

J. A. Wilson, 723-A

Document Control, 703-43A 